\title{
The role of protected areas in destination choice in the European Alps
}

\begin{abstract}
This paper investigates the role of protected areas (PA) for destination choice in the European Alps. It is based on the analysis of the most relevant types of PA (national park, nature park, biosphere reserve), constituting part of the supply of tourism development, and a representative survey of the German population interested in holidays in the alpine area, representing the demand. Our analysis of the legal framework showed that all three types of PA facilitate tourism development, albeit in different ways. The survey included a generic choice experiment of alpine destinations with 17 attributes. Its location in or close to a PA was included as one variable. This destination demand study in an area of origin provided a different perspective on the preference for PA compared to other studies, and revealed significant differences between respondents with and without previous experiences in the Alps. The alpine experienced tourist is more likely to distinguish between the various types of PA such as national park and nature park. For the inexperienced alpine tourist, representing latent demand, the branding effect of PA is rather limited. For nearly all tourists, experienced and inexperienced, and across all segments, offers that include a nature experience are important. Nature experience, which is offered by all types of PA, is of high relevance within the destination choice and should therefore be used more intensely in destination marketing based on PA. Overall, this study shows that the role of PA for destination choice is not as strong as is reported by most of the published literature, as most of these studies are based on surveys in the destination and use single item scaling questions, which overvalue the role of PA.
\end{abstract}

Keywords: choice experiment, segmentation, study of origin, match of supply and demand, nature experience

\section{Introduction}

Economic development across the European Alps is becoming increasingly polarized. On the one hand, regional discrepancies are fueled by increasing metropolisation. For example, $73 \%$ of the Swiss population already lives in urban areas (PERLIK 2006). Similarly, the Austrian cities of Vienna and Graz continue to grow. On the other hand, many alpine valleys are facing a rapid depopulation of up to $13 \%$ per year (Statistik Austria 2012). The exceptions to this trend are regions with major winter sports destinations and regions around alpine cities.

The ongoing population decline in rural areas is mostly driven by the emigration of members of the younger generation in search of better job opportunities. The continuing downward spiral of rural regions and the associated increasing rural-urban dichotomies (see MesserLi 1989; BÄTZING 2002) are exaggerated further by declining investments into public infrastructure, insufficient public transportation, a declining quality of education, and the removal of all but basic social services (PRÖBSTL 2010). While the quality of infrastructure declines in the hinterland, the political goals and the goals for spatial planning - "the concept of the equality of living conditions" across all regions - remain the same in all alpine countries, although they seem to become ever more elusive. Recently, the Bavarian spatial development program repeated its commitment to equal living and working conditions across the state as its main guiding principle (StMWIVT 2013).

Whenever this discrepancy between regional development goals and the actual situation is discussed, the proposed solutions are rather similar: Rural and nature-based tourism and recreation are promoted as the major vehicles for keeping rural areas attractive and livable (GEORGE et al. 2009; ZANON/GENELETTI 2011). The tourism sector is expected to enhance the local economy, create new jobs, strengthen the regional identity 
and local brand, contribute to the financial basis, and secure and advance local infrastructure (e.g. SPÖ-Klubenquete 2012; ZURC 2008, 9).

At first glance, the international discussion about the future of rural tourism allows for cautious optimism. One significant trend in tourism is that, with the maturing of its main markets, a new tourist, who can be characterized as experienced, sophisticated and demanding, is emerging (CoOPER et al. 2005). COOPER et al. (2005) expect that the main market in developed countries will shift away from holidaying in a typical beach resort to multi-interest travel in search of creative and innovative travel experiences such as activity, adventure, learning and nature-based tourism.

Against this background, both tourism experts and politicians in the alpine areas have high hopes: tourism in the alpine area will be the main economic sector for solving the increasing problems of a declining economy, and will enhance regional development, especially outside of the winter sports destinations. One important pillar in this concept is the idea of marketing the outstanding natural integrity of the alpine area to visitors (PRÖBSTL 2010; HAMMER/SIEGRIST 2008). When it comes to marketing nature, unspoiled landscapes and sustainability, PA arguably constitute a crucial component of such a strategy (DIXON/SHERMAN 1991). Given ongoing discussions on this topic in most alpine countries, this paper investigates the current role and future potential of parks and protected areas for tourism development. For that purpose, we will consider both the demand side and the supply side of alpine tourism for the summer season, with a focus on the suitability of large-scale PA as vehicles for growth of tourism, and consequently as catalysts for regional development across the Alps.

\section{The role of protected areas for tourism development and destination choice}

Research on PA and their impact on tourism development has increased worldwide in the last decades (SCHEURER/KÜPFER 1997; KÜPFER 2000; EAGLES 2001; GetZNER/JungmeIER 2002; Hall/Piggin 2002; Mose/Weixlbaumer 2003; BuCKLEY 2004a; LeHAR et al. 2004; WeILER/ SEIDL 2004; KAMMER 2005; LeIBENATH/BADURA 2005; SCHMITZ-VELTIN 2005; SAAYMAN/ SAAYMAN 2006; Siegrist et al. 2007; WeIXLBAUMER et al. 2007; Gurung/SEELAND 2008;
HAMmer/Siegrist 2008; JoB et al. 2005; VDN 2010; PröBStl et al. 2010; Higgins-DesBiolles 2011; JoB 2013; BACKHAUS et al. 2013, MAYER/ JoB 2014). EAGLES $(2001,16)$ estimated the economic benefit of park tourism in Canada and the USA at about 236-370 bn US\$ annually. Park tourism also generated a significant direct income in the alpine area. For the Swiss National Park KÜPFER (2000) reported a direct economic impact of 9 to $13 \mathrm{~m}$ Swiss francs (CHF) per year, which BACKHAUS et al. (2013) re-estimated at $17,4 \mathrm{~m} \mathrm{CHF}$ annually with indirect effects to the region added. JoB et al. (2003) documented similar economic effects for the Berchtesgaden National Park in Germany. FleISCHHACKeR/ PAUER (2001) analyzed the effects of all Austrian National Parks on tourism and regional development. They showed that, in addition to the direct economic benefit, the presence of national parks in a region also increased the duration of stays significantly, especially for years with poor weather conditions during summer, when sojourns in national park regions were one day longer compared to other destinations. Besides the economic impact of national parks, the economic effects of other conservation categories on tourism have also been studied.

PRÖBSTL/WIRTH (2011) reported daily expenses of around $60 €$ per person during the summer months, accruing from the nature park Mürzer Oberland in the Austrian Alps. Studies by HeINTEL/Weixlbaumer (2009) in four different nature parks in Austria and TemPesta/Thiene (2000) for the nature park of the Ampezzo Dolomites in Italy support these findings. LEHAR et al. (2004) identified an annual economic impact of $1.94 \mathrm{~m} €$ per year in the nature park RieserfernerAhrn in the Italian Alps. A recent study showed that the economic impact of the Swiss National Park and the Biosfera Val Müstair combined is six times higher than the annual investment by the state and the cantonal government (BACKHAUS et al. 2013). JoB et al. (2013) summarized the economic effects of six German biosphere reserves on tourism, and they also emphasized the increasing potential for successful destination marketing. The above figures also confirm that economic benefits are generated by various types of PA. PA comparisons between nature parks and national parks showed clearly that the economic impact is not a function of the degree of protection or type of park, but rather depends on other factors such as types of landscape, management, infrastructure and product development (JoB et al. 2003; PRÖBSTL-HAIDER 2013). 
In addition to the economic benefits, the relevance of protected areas in the process of destination choice has been studied widely (Tab. 1). It has been a significant field of research since the 1980s (e.g. MATHIESON/WALl 1982, 28; WoODSIDE/LYSONSKI 1989, 9) when the main aim was to understand, anticipate and model travelers' decisions. Key components of all these models are the tourists themselves (including their lifestyles, values, experiences and socio-economic and behavioral characteristics), information and marketing (including product design, pricing, advertising, travel arrangements) and the attributes of the destination (including accommodation, activities, local attractions and landscape characteristics) (MARCH/WOODSIDE 2005, 142; WoOdSIDE/KING 2001). The main aim of our paper is to study the role of a protected area within the complex trade-offs that travelers face when selecting an alpine vacation. One early concept to understand individual decision making in destination choice was the "theory of planned behavior" (TPB) by AJZEN (1985, 1991). Recently, this approach and its applications in tourism have been criticized by researchers investigating consumer behavior in detail (MARCH/ WoOdside 2005; BAgOzZI/NATARAAJAN 2000; PRÖBSTL-HAider/Haider 2013). While the TPB is useful for understanding decisions, it is less suitable for predicting outcomes. The analyzed attitudes only provide limited information about the trade-offs within a destination choice. Destination attributes in the alpine area are complex and include sports facilities, events, settlement structure, shopping opportunities, the surrounding environment (including protected areas) and many others. The methodological review in Tab. 1 shows four main approaches to studying the influence of PA on destination choice. The first group of studies is based on revealed preferences using data from official tourism statistics such as community accommodation records. A second group of research uses questionnaires to ask tourists in national parks about the importance or role the PA played for their visit. These on-site studies mainly used Likert-scale questions to evaluate the relevance of PA. The third group of studies is also based on questionnaires, but models actual behavior or intended behavior based on the "random utility theory" (RUT). Here, the actual observed choice (revealed preference or choice) or the intended choice among hypothetical alternatives (stated preferences or choice) serve as the dependent variable, which is explained as a function of other product or service characteristics. RUT postulates that the utility of an alternative is a function of its components, and that individuals maximize their overall utility when making choices (TRAIN 2003). The discrete choice experiment allows the measurement of the importance of one single attribute, such as the PA, in the context of many other relevant attributes. Finally, a number of studies in regions of origin also used questionnaires and one-dimensional analyses to ascertain the relevance of PA.

Most of the studies in Tab. 1 revealed positive effects. However, some critical outcomes should also be mentioned. BUCKLEY (2004) did not find a significant increase of attention associated with newly branded world heritage sites. PRÖBSTL/ WIRTH (2011) reported the significant relevance of activities in Austrian nature parks, and REINIUS/FREDMAN (2007) explicitly mentioned the differing recognition of various types of PA. However, THOMPSON (2008) and FRANCH et al. (2008) already discuss limits for further developments in PA in proximity to winter sports destinations in France and Italy.

Due to the wide range of positive experiences, many authors argue that destination marketing should also take advantage of parks and PA and should communicate the label of PA better (ForSTER/SIEGRIST 2009; WiRTH 2010). PA allow the destination to establish and communicate a more unique profile by distinguishing itself from other destinations.

Many authors emphasize that increasing mobility and the increasing sophistication of tourists will continue to make marketing efforts more important (COOPER et al. 2005, 779; HANNEMANN/ JoB 2003, 14). PA certainly constitute one opportunity among several to communicate a unique selling proposition, as the label national park or nature park already constitutes by itself a national or even international brand. Destination branding requires a clear understanding of the key terms and their respective meaning. It will only be effective if the brand is well known, well introduced and ensures a certain quality (LIPING 2002; PRÖBSTL 2006).

Most studies on the effects of PA have been conducted at the destination, in the sense that these data rely on surveys of actual visitors to a given destination (see Tab. 1). Consequently, the positive effect of PA for destination choice may be overestimated because these studies only interview people who have already self-selected 
Tab. 1: Studies on the influence of protected areas on destination choice

\begin{tabular}{lllll}
$\begin{array}{l}\text { Study } \\
\text { protected area }\end{array}$ & $\begin{array}{c}\text { Type of } \\
\text { in destination choice }\end{array}$ & Reference area & Method \\
\hline $\begin{array}{llll}\text { Studies on destination area for the relevance of protected areas in the destination choice-existing data } \\
\text { WEILER/SEIDL } \\
(2004)\end{array}$ & National park & $\begin{array}{l}\text { Significant increase of attendances, } \\
\text { on average 11 642 visitors }\end{array}$ & $\begin{array}{l}\text { Newly designated } \\
\text { national parks in USA } \\
\text { since 1979 }\end{array}$ & $\begin{array}{l}\text { Travel cost } \\
\text { demand model }\end{array}$ \\
\hline BUCKLEY (2004) & $\begin{array}{l}\text { World } \\
\text { heritage site }\end{array}$ & $\begin{array}{l}\text { No significant increase of } \\
\text { attendances }\end{array}$ & $\begin{array}{l}\text { 6 Australian national } \\
\text { parks, which were } \\
\text { designated as world } \\
\text { heritage sites }\end{array}$ & $\begin{array}{l}\text { Analysis of } \\
\text { visits }\end{array}$ \\
\end{tabular}

\begin{tabular}{lccc}
\hline $\begin{array}{l}\text { FLEISCHHACKER/ } \\
\text { PAUER (2001) }\end{array}$ & National park & Longer duration of stay in parks & $\begin{array}{l}\text { Austrian national parks } \\
\text { Analysis based } \\
\text { on accommoda- } \\
\text { tion statistics }\end{array}$ \\
\hline
\end{tabular}

Studies on destination area for the relevance of protected areas in the destination choice-questionnaires

\begin{tabular}{|c|c|c|c|c|}
\hline $\begin{array}{l}\text { KLEINHENZ } \\
(1985)\end{array}$ & National park & $\begin{array}{l}\text { Main reason: } 5 \% \text { of respondents, } \\
\text { Impact: } 25 \% \text { of respondents, } \\
\text { Partial impact: } 5 \% \text { of respondents }\end{array}$ & $\begin{array}{l}\text { Questionnaire in the } \\
\text { National Park Bayeri- } \\
\text { scher Wald }\end{array}$ & $\begin{array}{l}\text { Uni-dimensional } \\
\text { analysis }\end{array}$ \\
\hline GMWC (1995) & National park & $\begin{array}{l}\text { Crucial role: } 18 \% \text { of respondents, } \\
\text { Important role: } 50 \% \text { of respondents }\end{array}$ & $\begin{array}{l}\text { Questionnaire in } \\
\text { German national parks }\end{array}$ & $\begin{array}{l}\text { Uni-dimensional } \\
\text { analysis }\end{array}$ \\
\hline $\begin{array}{l}\text { OBUA/HARDING } \\
(1996)\end{array}$ & National park & $\begin{array}{l}\text { Crucial role: } 29 \% \text { of respondents, } \\
\text { Important role: } 35 \% \text { of respondents }\end{array}$ & $\begin{array}{l}\text { Questionnaire in the } \\
\text { National Park Kibale, } \\
\text { Uganda }\end{array}$ & $\begin{array}{l}\text { Uni-dimensional } \\
\text { analysis }\end{array}$ \\
\hline KÜPFER (2000) & National park & $\begin{array}{l}\text { Vital importance for } 23 \% \text { of respon- } \\
\text { dents in national park, } \\
\text { Extended circle: } 69 \%\end{array}$ & $\begin{array}{l}\text { Questionnaire in the } \\
\text { Swiss National Park }\end{array}$ & $\begin{array}{l}\text { Uni-dimensional } \\
\text { analysis }\end{array}$ \\
\hline $\begin{array}{l}\text { LEHAR et al. } \\
(2004)\end{array}$ & $\begin{array}{l}\text { National park, } \\
\text { nature park }\end{array}$ & $\begin{array}{l}\text { Vital importance resp. additional } \\
\text { incentive: } 50 \% \text { of respondents in } \\
\text { national park, } \\
39 \% \text { in nature park }\end{array}$ & $\begin{array}{l}\text { Questionnaire in the } \\
\text { National Park Hohe } \\
\text { Tauern and in the Nature } \\
\text { Park Riesenferner-Ahrn }\end{array}$ & $\begin{array}{l}\text { Uni-dimensional } \\
\text { analysis }\end{array}$ \\
\hline JoB et al. (2005) & $\begin{array}{l}\text { National park, } \\
\text { nature park }\end{array}$ & $\begin{array}{l}\text { Very high or high importance: } 44 \% \\
\text { of respondents in national park (pro- } \\
\text { tection status known), } 31-39 \% \text { in } \\
\text { nature park (protection status } \\
\text { known) }\end{array}$ & $\begin{array}{l}\text { Questionnaire in } \\
\text { National Parks Müritz } \\
\text { and Berchtesgaden, } \\
\text { Nature Parks Altmühltal } \\
\text { and Hoher Fläming }\end{array}$ & $\begin{array}{l}\text { Uni-dimensional } \\
\text { analysis }\end{array}$ \\
\hline $\begin{array}{l}\text { WEIXLBAUMER } \\
\text { et al. (2007) }\end{array}$ & Nature park & $\begin{array}{l}\text { Very high or high importance: } 34 \% \\
\text { of respondents in nature park (pro- } \\
\text { tection status was partly not known) }\end{array}$ & $\begin{array}{l}\text { Questionnaire in the na- } \\
\text { ture parks in Burgenland, } \\
\text { Austria }\end{array}$ & $\begin{array}{l}\text { Uni-dimensional } \\
\text { analysis }\end{array}$ \\
\hline $\begin{array}{l}\text { REINIUS/ } \\
\text { FREDMAN (2007) }\end{array}$ & $\begin{array}{l}\text { National park, } \\
\text { world heritage } \\
\text { site, biosphere } \\
\text { reserve }\end{array}$ & $\begin{array}{l}\text { National park: } 44 \% \text { of respondents, } \\
\text { World heritage site*: } 5 \% \text { of respon- } \\
\text { dents, } \\
\text { Biosphere reserve*: } 1 \% \text { of respon- } \\
\text { dents* additionally designated as na- } \\
\text { tional park }\end{array}$ & $\begin{array}{l}\text { Questionnaire in: } \\
\text { Fulufjället National Park, } \\
\text { Laponian World Heritage } \\
\text { Site, Lake Torne Bio- } \\
\text { sphere Reserve }\end{array}$ & $\begin{array}{l}\text { Uni-dimensional } \\
\text { analysis }\end{array}$ \\
\hline $\begin{array}{l}\text { PRÖBSTL/WIRTH } \\
\text { (2011) }\end{array}$ & Nature park & $\begin{array}{l}\text { Minor effects, activities more } \\
\text { relevant }\end{array}$ & $\begin{array}{l}\text { Questionnaire in the } \\
\text { Nature Park Mürzer } \\
\text { Oberland, Austria }\end{array}$ & $\begin{array}{l}\text { Uni-dimensional } \\
\text { analysis }\end{array}$ \\
\hline $\begin{array}{l}\text { BACKHAUS et al. } \\
\text { (2013) }\end{array}$ & $\begin{array}{l}\text { National park, } \\
\text { biosphere } \\
\text { reserve }\end{array}$ & $\begin{array}{l}\text { National park is more relevant than } \\
\text { biosphere reserve. } \\
\text { Economic impact by NP } 28.4 \% \text { ver- } \\
\text { sus } 6.6 \% \text { in BR }\end{array}$ & $\begin{array}{l}\text { National Park Switzer- } \\
\text { land, Biosphere Reserve } \\
\text { Val Müstair }\end{array}$ & $\begin{array}{l}\text { Uni-dimensional } \\
\text { analysis }\end{array}$ \\
\hline JoB et al. (2013) & $\begin{array}{l}\text { Biosphere } \\
\text { reserves }\end{array}$ & $\begin{array}{l}\text { Comparison of } 6 \text { case studies, little } \\
\text { but increasing relevance }\end{array}$ & Germany & $\begin{array}{l}\text { Uni-dimensional } \\
\text { analysis }\end{array}$ \\
\hline
\end{tabular}




\begin{tabular}{|c|c|c|c|c|}
\hline Study & $\begin{array}{c}\text { Type of protected } \\
\text { area }\end{array}$ & $\begin{array}{l}\text { Results: Relevance of protected area } \\
\text { in destination choice }\end{array}$ & Reference area & Method \\
\hline \multicolumn{5}{|c|}{ Studies on destination area for the relevance of protected areas in the destination choice-stated preference methods } \\
\hline $\begin{array}{l}\text { BRAU/CAO } \\
(2005)\end{array}$ & $\begin{array}{l}\text { Nature } \\
\text { reserve }\end{array}$ & Significant impact in total sample & $\begin{array}{l}\text { Questionnaire of } \\
\text { travelers on departure } \\
\text { from Sardinia }\end{array}$ & $\begin{array}{l}\text { Discrete choice } \\
\text { experiment }\end{array}$ \\
\hline ENGLUND (2005) & Not specified & Significant impact in total sample & $\begin{array}{l}\text { Questionnaire of summer } \\
\text { tourists in Whistler, BC }\end{array}$ & $\begin{array}{l}\text { Discrete choice } \\
\text { experiment }\end{array}$ \\
\hline $\begin{array}{l}\text { KELLY et al. } \\
(2007)\end{array}$ & Not specified & Significant impact in total sample & $\begin{array}{l}\text { Questionnaire of summer } \\
\text { tourists in Whistler, BC }\end{array}$ & $\begin{array}{l}\text { Discrete choice } \\
\text { experiment }\end{array}$ \\
\hline $\begin{array}{l}\text { LANDAUER et al. } \\
\text { (2014) }\end{array}$ & Not specified & Significant positive influence & $\begin{array}{l}\text { Questionnaire on } \\
\text { cross-country skiers in } \\
\text { the Alps, Austria }\end{array}$ & $\begin{array}{l}\text { Discrete choice } \\
\text { experiment }\end{array}$ \\
\hline \multicolumn{5}{|c|}{ Studies on source region for the relevance of protected areas in the destination choice-questionnaires } \\
\hline $\begin{array}{l}\text { WWF Deutsch- } \\
\text { land (1999) }\end{array}$ & National park & $\begin{array}{l}\text { Prefer vacation where areas are de- } \\
\text { signated for protection of landscape: } \\
72 \% \text { of respondents }\end{array}$ & $\begin{array}{l}\text { Germany-wide } \\
\text { questionnaire }\end{array}$ & $\begin{array}{l}\text { Uni-dimensional } \\
\text { analysis }\end{array}$ \\
\hline $\begin{array}{l}\text { Studienkreis für } \\
\text { Tourismus und } \\
\text { Entwicklung } \\
\text { (2005) }\end{array}$ & $\begin{array}{l}\text { Nature or } \\
\text { national park }\end{array}$ & $\begin{array}{l}\text { Possibility to visit a nature or } \\
\text { national Park is important for } \\
\text { destination choice: } \\
33 \% \text { of respondents }\end{array}$ & $\begin{array}{l}\text { Germany-wide } \\
\text { questionnaire }\end{array}$ & $\begin{array}{l}\text { Uni-dimensional } \\
\text { analysis }\end{array}$ \\
\hline
\end{tabular}

Source: expanded after Wirth 2010

themselves to visit PA. On the other hand, a critical observation of tourism research on destination choice reveals that the role of nature and PA for the attractiveness of destinations has so far received surprisingly little attention - except for the studies by BRAU/CAO (2005), ENGLUND (2005), KeLLY et al. (2007) and LANDAUER et al. (2014). Given these two significant gaps in tourism research, we perceived a timely need for a study that combines the importance of PA in the context of destination choice with the overall demand characteristics for alpine tourism in one of the major areas of origin.

With regards to the supply of PA in the alpine area it is important to differentiate between the different types of protected areas, which is essential for any destination branding. LIPING $(2002,725)$ illustrates that a strong brand identity can be developed based on an existing induced image, with additional marketing programs addressed to the target markets. The different types of protected areas may contribute to an existing image in several ways and might be strengthened further with more brand image building. Studies analyzing the target markets are helpful to explore the perceived brand identities and the marketing potential in various destinations. The existing induced image of a PA is also influenced by its legal definition and its main goals, both of which depend on its type. Therefore, in order to study the effects of PA on tourism, one should study both: the demand side and the supply side. Overall, the paper will pursue the following research questions:

- Is the branding and marketing of destinations based on PA as relevant as reported in the literature?

- Do tourists differentiate between the three categories of PA (nature park, national park and biosphere reserve) in their destination choice process?

- What is the effect of PA on destination choice compared to other attributes?

- How significant are offers of a nature experience for destination choice?

\section{Methodological approach}

We investigate these research questions with a two-pronged approach. An analysis of the supply of PA in the entire alpine region will entail a comparative evaluation of the role of parks and PA as a resource base for tourism. The comparisons will focus on the most effective, large 
types of PA: national parks, nature parks, and biosphere reserves. The analysis of the demand for PA in the Alps will be based on the results of one online survey of a representative sample of potential German travelers, who are arguably the most important target group for summer visits to the alpine area, at least in Austria, Italy and Switzerland.

\section{Methodological approach to study the supply side}

The analysis of supply considers the three main types of large-scale PA (national parks, nature parks and biosphere reserves) and evaluates them comparatively in their ability to accommodate tourists and to support tourism development. Other types of PA have not been considered, because these types

- are less effective for tourism development because of their restricted physical size (such as the nature protection areas),

- may exist in some of the alpine countries only and are therefore not relevant for destination marketing across the entire alpine area,

- have been defined as a tool to prevent significant tourism development, such as the "Ruhezone" ("quiet zone") in Tyrolean conservation law, which protects nature from further disturbances by tourists, or

- limit tourism activities entirely, such as wilderness areas (usually large scale areas in which tourism activities are legally restricted - e.g. Wilderness Area Dürrenstein in Austria).

We analyzed the legal frameworks in all seven alpine countries (and regions, if relevant) in order to check whether the respective conservation laws define similar functions for national parks, nature parks and biosphere reserves. Although the legal documents differ significantly across the alpine countries (37 national or regional conservation laws are applicable), the analysis showed that the legal concepts for the largescaled PA are highly comparable and follow similar principles. This finding is in line with the analysis by the Netzwerk alpiner Schutzgebiete (2002). Therefore, it was sufficient to evaluate the role of PA for tourism development conceptually, for each type of protected area only, without concern for the specific countries. For the evaluation of the supply side, we developed a set of criteria gleaned from the conservation literature (IUCN 1994; OlsChOWy 1979; AlPARC 2002) and tourism literature (SIEGRIST/STREMLOW 2009, 239 f., Siegrist/WASEm 2009, 157; PrÖBSTl 2006; PröBstl et al. 2010; COOPER et al. 2005, $353 \mathrm{f}$.) and organized under three aspects:

1. Criteria based on conservation legislation which may lead to restrictions on tourism development, such as

- scientific research,

- protection of biodiversity,

- maintenance of ecological functions.

2. Criteria based on conservation legislation which is relevant for tourism development, such as

- protection of cultural elements and landscape beauty,

- sustainable regional development,

- environmental education,

- development for tourism and outdoor recreation,

- enhancement and maintenance of sustainable land use,

- protection and maintenance of cultural assets.

3. Criteria relevant for destination marketing and management, such as

- suitability for product development,

- suitability for destination branding.

We will use these criteria to evaluate the suitability of the three main large scale types of PA in the Alps (national parks, nature parks and biosphere reserves) for accommodating tourism uses.

The first set of criteria indicates to what extent a protected area may restrict or limit tourism use and development. Such restrictions may be of fundamental importance, because scientific research on biodiversity requires undisturbed environmental conditions. Similar requirements exist for species and habitat protection, and the contribution to or maintenance of the ecological functions (AMMER/PröBSTL 1991; IUCN 1994; DEL Negro 2009). These restrictions often lead to zoning concepts with a reduced accessibility for tourists and the public. 
The second set of criteria addresses the need for unspoiled attractive landscapes for tourism purposes. It includes attractive natural landscapes, mainly provided by national parks, and cultural landscapes, mainly offered by nature parks and biosphere reserves. Therefore, these criteria are also closely associated with the essential avoidance of intensive land uses, usually forestry or agriculture (AMMER/PrÖBSTL 1991; HAIDER/ HUNT 2002; HuNZIKER et al. 2008). The importance of sustainable and extensive land use by PA has been highlighted by many studies in different alpine countries (PRÖBSTL 2004; JOB et al. 2003; WeIXLBAumer et al. 2007; Siegrist/ Stremlow 2009; SchweIgGl 1993). Therefore, Biosphere reserves as well as nature parks help to maintain cultural landscapes, which are highly attractive for tourists as well (Јов et al. 2013).

The third set of criteria focuses on the use of PA for destination branding and marketing. Here, the main focus is on making use of the public familiarity of the various types of PA. While the concept of national parks has already been discussed in Europe since 1900, the concept of nature parks was only developed in the late $1950 \mathrm{~s}$, and the concept of the biosphere reserves, dating back to the 1970s, is even younger. From the perspective of tourism development, it is important to consider the various opportunities offered by different types of parks to develop new tourism products and relevant support infrastructure. The role of PA is sometimes perceived as an active one for tourism development, and sometimes as more passive - for example if the development of new products is not considered very important (see Tab. 1).

\section{Methodological approach to study the demand side}

In many cases, such as studies by Austrian Tourism (Österreich Werbung), research about motivation and the main attractions to a destination have reported very positive perceptions of PA. Once tourists have actually visited a location, chances are that they will be satisfied with their decision (WIRTH 2010). In order to avoid this bias in a study and to learn more about the relevance of nature, natural experiences and PA for destination choice, we selected from an online panel in Germany a representative sample of German travelers, who are the most important target group for the summer season in many alpine regions. Such panels provide a large data- base for representative studies, and tests have confirmed their excellent suitability for representative studies (KORNMÜLLER 2008).

Overall, 1135 respondents (return rate of $54 \%$ ) provided detailed information about their PA travel behavior to the Alps, explained circumstances around their choices, and also completed a discrete choice experiment (BOXALL/ADAMOWICZ 2002; CAMPBELL/HutCHISON 2006; LouVIERE et al. 2000). The choice sets were designed in a visually appealing way, by resembling the typical website of an alpine destination, to keep the respondents engaged and to make the choice task as realistic as possible. Only respondents with an interest (i. e. with or without actual experience) in alpine destinations received the discrete choice experiment. Each of these respondents was given six choice sets requiring a choice between two hypothetical alpine destinations. Each destination was described by its most salient attributes, including size of the settlement, shopping opportunities, offers for sports and outdoor recreational activities, as well as offers for events, nature experience and environmental learning (Tab. 2).

An orthogonal fractional factorial design was used to select a small number of these combinations for the survey instrument (LOUVIERE et al. 2000; Hensher et al. 2005). Thus, only 72 choice sets were required to estimate all main effects and select interaction effects.

Discrete choice experiments have been applied to investigate many different types of destination choices (PröBSTl-Haider/Haider 2013; Haider/Ewing 1990; Morley 1994; SCHLich et al. 2002; Huybers 2004; Brau/CaO 2005; SCARPa/Thieme 2005; Kelly et al. 2007). Findings of these studies show that the multi-attribute method is very suitable for investigating tourists' responses in a complex decision situation, as this method makes it possible to account for different attributes in relation to each other and to model trade-offs between various attributes (LOUVIERE/ TIMMERMANS 1990).

However, so far no study has investigated preferences for PA and several other destination characteristics in a tourism origin area. Analysis of the survey data was conducted in SPSS 15.0 (SPSS Inc. 1989-2006), and the choice experiment in Latent GOLD Choice 4.0. The segments were compared with T-Test, $\mathrm{Chi}^{2}$ according to Pearson and Analysis of Variance (ANOVA), 
Tab. 2: Attributes used in the choice experiment

\begin{tabular}{ll} 
Thematic field & Attributes \\
\hline Landscape & Landscape \\
1 & Protected Areas \\
2 & \\
\hline Location & Size (inhabitants) \\
3 & Character \\
4 & Nature experience offers \\
5 & \\
\hline Climate & Days of sun in the summer period \\
6 & Hiking \\
\hline Sports and Activities & Mountain biking \\
7 & Climbing, fixed rope routes \\
8 & Horse-riding \\
9 & Golfing \\
10 & Swimming \\
11 & Indoor offers \\
12 & Price level \\
13 & Cultural offers \\
\hline Cultural offers & Traditional offers \\
14 & Events \\
15 & \\
\hline Price & \\
17 & \\
\hline
\end{tabular}

Source: own survey

and CHAID analyses were also applied (WIRTH 2010; PRÖBSTL-HAIDER et al. 2014). The overall results of the choice experiment are presented in the Annex. In the analysis below we will present the detailed findings for the attributes "PA" and "nature experience" only.

\section{Results}

\section{Alpine tourism and PA - the supply side}

The alpine area contains large tracts of land with unspoiled nature and impressive virgin landscapes on the one hand, and a high diversity of cultural landscapes on the other. The seven European alpine countries aim to protect this rich biodiversity in a network of more than 1000 PA of larger than 100 ha, covering about $25 \%$ of the alpine region, as documented by the Alpine Convention (G.I.S. Alparc 2013). Of particular relevance for tourism development and tourism marketing are the 14 national parks, 75 nature parks and 10 biospherereserves (KOHLER 2013). These larger-scale PA differ significantly in their goals and relevance for nature conservation and for tourism related regional development. In the following, their legal and regulatory frameworks will be evaluated comparatively according to their suitability to support tourism development. The main findings are summarized in Tab. 3 .

Regarding the three conservation oriented criteria, national parks offer the strongest degree of protection. In most cases, this protection is afforded by zoning systems and regulated access, at least in some core areas. This is also true for biosphere reserves, which have similar regulatory restrictions in the core zone, but less so in the other zones. The protective function of nature parks, in contrast, is of minor importance since this type of protected area was developed primarily for outdoor recreation and landscape experience. However, over the past 50 years, the importance of conservation has somewhat increased in nature parks, but protection and maintenance of the ecological functionality occur on cultivated land, and therefore do not exclude recreation and tourism activities, nor a range of other land uses.

The set of criteria based on conservation law and relevant for tourism development indicate that the nature park is explicitly designed for the protection of cultural elements and landscape aesthetics, as well as the maintenance of cultural assets and sustainable land use. This focus, combined with a significant offer of environmental education, development of tourism, and recreation and tourism related products, illustrates the high relevance of nature parks for naturebased tourism. The biosphere reserve has similar goals, especially in the field of sustainable land use and regional development, but is - according to the legal background - less tourism and recreation oriented. Recent studies on biosphere reserves showed that, in these areas, the role of tourism as a tool for regional development is less frequent than in the other types of PA (JOB et al. 2013).

In the national park, the infrastructure and activities for environmental education, including visitor centers, often play a significant role as tourism attractions - even if, in many cases, the park itself has certain restrictions on access and on the types of outdoor recreation activities permitted. Thus, although the legal context of 
Tab. 3: Tourism development opportunities in different types of PA based on conservation law and public familiarity

\begin{tabular}{|c|c|c|c|c|}
\hline \multicolumn{4}{|c|}{ Type of protected area } & \multirow[b]{2}{*}{ Additional comments and national differences } \\
\hline & $\begin{array}{l}\text { National } \\
\text { park }\end{array}$ & $\begin{array}{l}\text { Nature } \\
\text { park }\end{array}$ & $\begin{array}{l}\text { Biosphere } \\
\text { reserve/park }\end{array}$ & \\
\hline \multicolumn{5}{|c|}{ Criteria based on conservation law which may lead to restrictions for tourism development } \\
\hline Scientific research & +++ & + & ++ & $\begin{array}{l}\text { In French national parks, research is no primary goal } \\
\text { Some Italian nature parks also add research to their } \\
\text { goals (e.g. South Tyrol, Trento). }\end{array}$ \\
\hline $\begin{array}{l}\text { Protection of biodiversity } \\
\text { (species and habitats) }\end{array}$ & +++ & + & ++ & $\begin{array}{l}\text { The importance of nature conservation is limited in } \\
\text { older nature parks in Austria (in Styria it is more pro- } \\
\text { minent). In Italy it is highly relevant in nature parks. }\end{array}$ \\
\hline $\begin{array}{l}\text { Maintenance of the } \\
\text { ecological functionality }\end{array}$ & +++ & + & ++ & $\begin{array}{l}\text { No significant differences between the respective } \\
\text { countries }\end{array}$ \\
\hline
\end{tabular}

Criteria based on conservation law and relevant for tourism development

Protection of cultural ele- $\quad+\quad+++\quad++\quad$ In Italy, nature parks are less relevant for the maintements and landscape beauty nance of cultural elements and landscape beauty

Sustainable regional $\quad+\quad+++\quad+++\quad$ National parks are nowadays often perceived as the
development key players for sustainable regional development, the legal framework in the respective countries does not support this goal.

\begin{tabular}{|c|c|c|c|c|}
\hline Environmental education & +++ & +++ & + & $\begin{array}{l}\text { No significant differences between the respective } \\
\text { countries }\end{array}$ \\
\hline $\begin{array}{l}\text { Development for tourism } \\
\text { and recreation }\end{array}$ & ++ & +++ & ++ & $\begin{array}{l}\text { Zoning concepts in national parks and biosphere } \\
\text { reserves reduce the options for touristic developmen } \\
\text { (e.g. limited access). The Swiss National Park has } \\
\text { significant restrictions everywhere. }\end{array}$ \\
\hline $\begin{array}{l}\text { Enhancement and } \\
\text { maintenance of sustainable }\end{array}$ & + & +++ & +++ & $\begin{array}{l}\text { No significant differences between the respective } \\
\text { countries. }\end{array}$ \\
\hline
\end{tabular}

land use

\begin{tabular}{lllll}
\hline $\begin{array}{l}\text { Protection and maintenance } \\
\text { of cultural assets }\end{array}$ & + & +++ & +++ & $\begin{array}{l}\text { No significant differences between the respective } \\
\text { countries. }\end{array}$ \\
\hline \begin{tabular}{llll} 
Criteria relevant for destination marketing and management \\
\hline $\begin{array}{l}\text { Suitability for product } \\
\text { development in tourism }\end{array}$
\end{tabular}$\quad+\quad+++$ & +++ & $\begin{array}{l}\text { The effects of nature parks in Austria are partly } \\
\text { limited because the size of some parks is too small. }\end{array}$ \\
\hline $\begin{array}{l}\text { Suitability for destination } \\
\text { branding (public familiarity) }\end{array}$ & +++ & +++ & + & $\begin{array}{l}\text { The effects of nature parks in Austria are partly } \\
\text { limited because the size of some parks is too small. }\end{array}$ \\
\hline
\end{tabular}

\footnotetext{
Key:

++ primary objective of this type of protected area in the Alps

++ secondary objective

+ minor importance, but possible

Source: own compilation
}

national parks does not require that they contribute to the sustainable development of rural or peripheral areas, in practice they may do so nonetheless. The increasing number of studies on the economic benefits of national parks further confirms this argument. In other words, one can often observe a discrepancy between the strict legal context and the expected outcome.
The evaluation of the criteria for destination marketing and management indicates that the nature park and the biosphere reserve both share sustainable regional development as their main mandate, and thus are highly suitable for the development of new products in tourism. Rural tourism and nature-based tourism products are also very likely to support the main- 
tenance of cultural landscapes and sustainable land use, which are also primary management objectives of these types of PA. It comes as little surprise that it is easier and less conflicting to integrate tourism facilities and new infrastructure in these mainly anthropogenic landscapes.

Finally, all three types of PA contribute to destination branding. This aspect is closely related to the general popularity of a given type of protected area. A survey in Austrian and German alpine tourism destinations (WIRTH/PrÖBSTL 2008) showed that national parks are the most popular type of protected area among tourists in the alpine area. The different history of the various types of parks (WEIXLBAUMER 2009, $191 \mathrm{f}$.) influences their popularity. For example, for most tourists, the biosphere reserve (or park) is still an unknown category of protected area and is therefore less suitable for destination branding (REINIUS/FrEDMAN 2007; JoB et al. 2013). This may change if international cooperation of these parks under the patronage of UNESCO will make them more visible.

\section{Alpine tourism and PA - the demand side}

The results of the representative survey in Germany showed that, overall, the alpine area is highly attractive for German tourists. About $89 \%$ of all respondents who travel regularly are principally interested in travel to the alpine area, while only $11 \%$ of that population is not interested in travel to the Alps at all. Their main reasons for neglecting the Alps are poor weather conditions and unattractive offers. This segment prefers sun and beach holidays. On the other hand, tourists interested in the alpine environment are attracted to unspoiled, idyllic landscapes, peace and freedom. Another important motivation is the interest in mountain related activities such as hiking and climbing. Further analysis of the data shows that tourism marketing should distinguish between clients who already have alpine experience and those who are interested but do not yet have any experience. For each of these two groups, three relevant sub-segments emerged (see Fig. 1 and 2).

The three segments of the "tourists with alpine experience" (57.5\% of the sample) were the traditional tourist $(48 \%)$, the social and sport oriented tourist $(41 \%)$, and the convenience oriented tourist $(11 \%)$. The role of PA and the relevance of nature experiences differ between these segments.

1. The traditional tourist prefers small mountain destinations, especially villages and a significant offer of hiking and climbing infrastructure. This segment is not interested in shopping, nightlife or large events. Demographically, this segment is dominated by elderly respondents $(56 \%$ are over 50 years of age). One very peculiar finding is that, although this group is highly interested in nature experience, they do not generally prefer destinations which are marketed as part of a protected area, with the exception of national parks. A typical tourism product for this segment is the "Bergsteigerdörfer" provided in Austria (www.bergsteigerdoerfer.at/), with unspoiled nature and sustainable tourism offers in small villages.

2. The social and sport oriented tourist prefers destinations which a broad and significant offer of all kinds of sports activities. In addition to hiking and climbing, this segment also enjoys mountain biking, swimming and golf. In contrast to the traditional tourist, visitors belonging to this segment also expect different kinds of events, such as festivals, concerts and exhibitions. Nature-based offers are less relevant, but they are attracted to nature parks.

3. The convenience oriented alpine tourist is characterized by rather unspecific requirements. Members of this segment are satisfied with basic hiking and swimming infrastructure. Cultural or event related programs are not relevant. Nature experience and educational offers are very welcome, but a destination in or in close proximity to a protected area does not constitute any added value to this segment.

The demands and expectations of each of these three segments are summarized in Fig. 1. It should also be noted that a marginal difference in price between products was not a discriminating factor between these segments, but that they differed solely in their motivation and preferred experiences.

The sample of "tourists without alpine experience" (but interested in travel in the Alps; $42.5 \%$ of the sample) could also be characterized by three different segments: The sport and action oriented potential tourist $(64 \%)$, the nature- 
Fig. 1: The role of PA for the three segments of the "tourist with alpine experience"

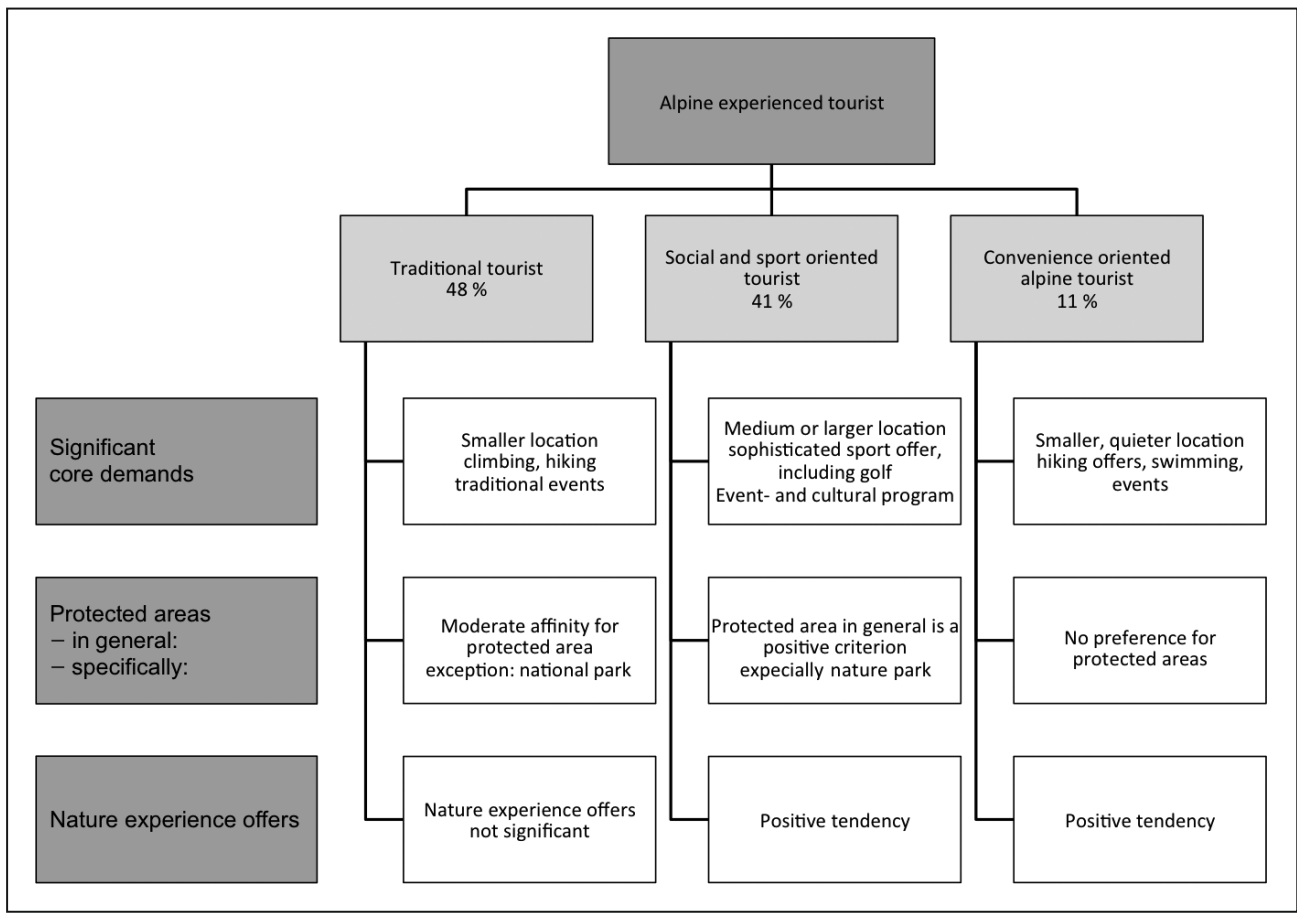

interested potential tourist $(23 \%)$ and the undemanding potential tourist (13\%) (Fig. 2).

1. The sport and action oriented potential tourist perceives the mountainous area as a kind of sports arena. All sports and action related offers should be of the highest quality, both outdoors and indoors. This segment showed a clear preference for larger destinations, which are able to ensure a broad spectrum of different events. None of the types of PA was considered important, but access to nature experiences was considered relevant. This segment is significantly younger and more pricesensitive compared to the two other segments without alpine experience.

2. The nature-interested potential tourist is in search of the opposite attributes compared to the previous segment. Members of this segment prefer small and quiet destinations with excellent hiking opportunities. Other offers such as mountain biking, climbing, horseback riding or golf are not relevant. They prefer only authentic cultural events, such as the "Almabtrieb" (local festival at the end of the cattle grazing season) or local theatre presentations. The segment clearly appreciates all types of PA included in the study. For them, a minimum level of protection seems to ensure the desired quality of the landscape and the respective tourism offer. However, they have no interest in nature experiences or nature education. This segment is dominated by female respondents over 40 years of age.

3. Finally, this breakdown of segments identified one rather unspecified undemanding potential alpine tourist. This group only requires some offers for swimming, hiking and indoor sports activities, as well as some preferably modern events, festivals or exhibitions. The analysis reveals a higher proportion of men over 50 years of age in this segment.

\section{Discussion}

Since the majority of tourists in the alpine countries originate from "developed" European 
Fig. 2: The role of PA and nature experience offers for the "tourist without alpine experience"

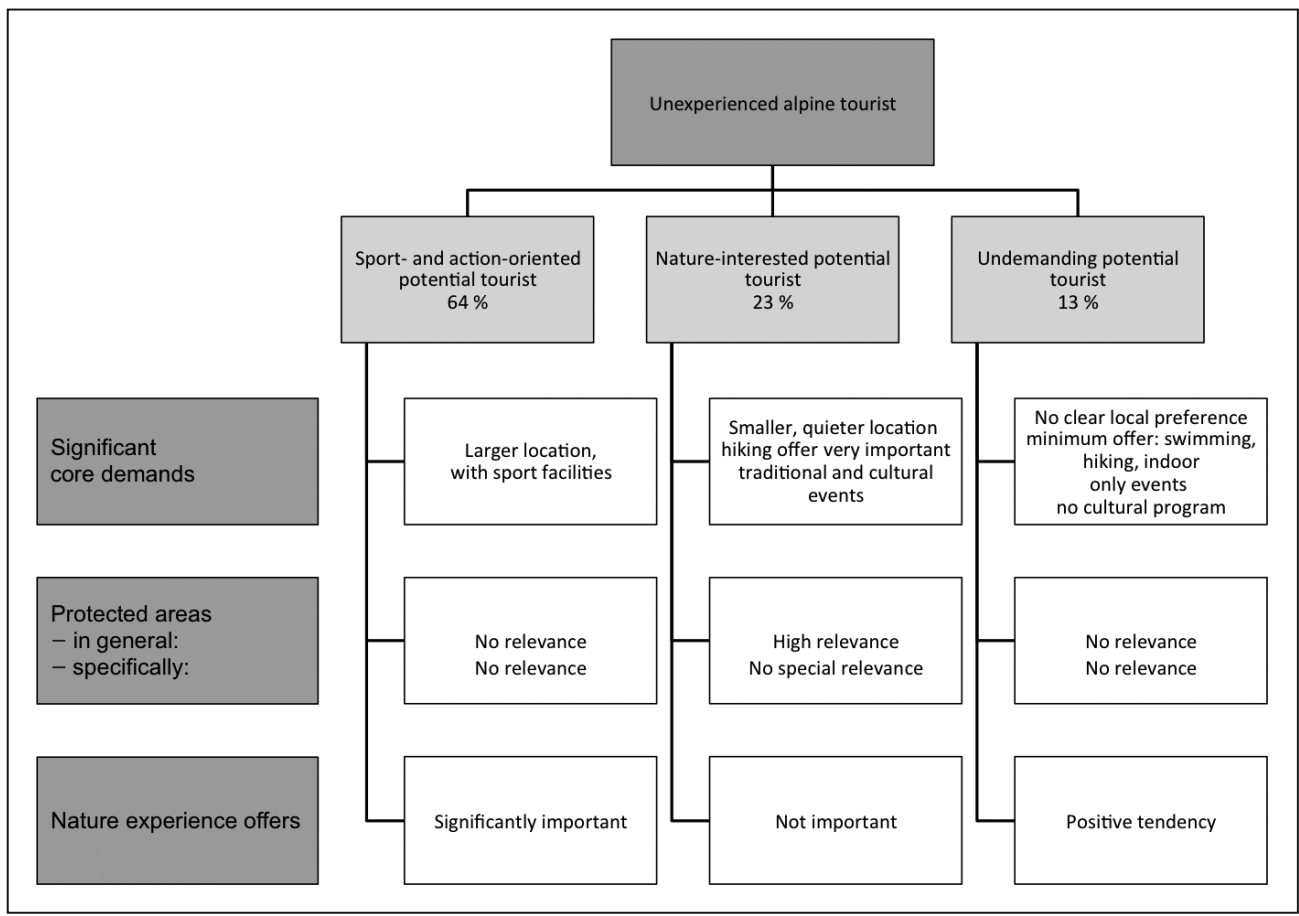

countries, the analysis of demand will focus on possible future developments associated with this type of tourist. Trend research describes the European tourist of the future as knowledgeable, discerning, quality-seeking and increasingly older (COOPER et al. 2005).

Trend research in Europe further highlights the increasing significance of nature and natural integrity. The Institute for Future Studies (KIRIG/ ScHICK 2008), for example, observes an increasing interest in nature. It perceives a new relevance of nature and the natural environment as an essential contrast to everyday life, offering a place for a change of pace and even spiritual experiences. Nature and natural environments are also considered ideal backdrops for stimulating learning processes. Nature offers space for enjoyment, for experiencing and taking delight in one's "self", and provides a place for testing limits and experiencing boundaries. KIRIG/SCHICK (2008) also describe a trend towards "outdoorcocooning": a natural environment is perceived as the ideal space for living, at least during the holidays. The authors believe that these trends will further increase the demand for close-tonature environments. The Tourismus Monitor Austria (T-MONA, Österreich Werbung 2012) has also observed an ever increasing importance of natural integrity and nature experience among its client surveys.

Other studies argue that this trend is also supported by demographic change. The elderly generation seems to be more attracted by naturebased tourism offers (BELL et al. 2009). GEORGE et al. (2009) explain this trend as an effect of globalization. The common feeling of being lost in a globalized world is compensated by a retreat into the private sphere or into a tourism product with a special regional authenticity and environmentally sound offer. PRÖBSTL et al. (2010) observe a trend towards activity in nature, as a contrast to the triviality and strict functionality of modern urban life. This change of lifestyle manifests itself in a revival of tourism products to do with pilgrimage and hiking, and nature related health products. It is against this background and generic trend that we want to discuss our main research questions. 


\section{Marketing, branding and nature experience based on $P A$}

The findings show that it is important to distinguish between tourists with and without former alpine experience when pursuing our original research question. PA are generally more relevant for those tourists who have already had former travel experience in the Alps. This means that largely the group of repeat visitors will be attracted by the marketing of destinations in or close to PA. These findings are in line with those of T-MONA (Österreich Werbung 2012). Since these studies for T-MONA are conducted on-site, they only consider experienced visitors (by definition) and are characterized by a high proportion of more frequent visitors. From our survey in the visitors' area of origin, we know that repeat visitors and those with former alpine experience are very likely to prefer PA. Therefore, these similarities are not surprising.

Additional surveys by WIRTH/PRÖBSTL (2007), asking tourists in the alpine destinations in Germany and Austria $(\mathrm{N}=412)$ about the marketing effect of PA, underline these findings as well. Here, the majority (over $80 \%$ ) agrees with the statement that "Protected areas contribute to the marketing of a destination". The somewhat ambivalent understanding of the term "protected area" by some respondents also became apparent in this study: $48 \%$ of respondents in Germany and 59\% in Austria also agreed with the statement that "Protected areas mean restrictions to outdoor recreation and tourism" (WIRTH/ PRÖBSTL 2007, 20 f.).

A second component for the marketing of PA in destinations (in addition to the brand name itself) are the recreation opportunities and infrastructure offered by the protected area, such as guided tours, environmental education programs and other offers to enhance nature experiences for tourists. Here, the findings show that most tourist segments are highly attracted by these offers, reflecting the increasing relevance of nature (KIRIG/SCHICK 2008) and experience-orientation (COOPER 2005) of tourists. PINE/GILMORE (1999) highlighted, already more than a decade ago, that tourism will become ever more driven by experiences. They suggested that simply being at a destination will become less relevant for the modern tourist, while the experiences on offer will become increasingly important for personal fulfillment and identity, and will play a more crucial role for destination choice in the future.
In our study, both the sport and action oriented potential tourists and the convenience oriented segments fall into this category. It seems that the brand names "national park", "nature park" or "biosphere reserve" communicate two aspects to the potential visitor: the context of more natural (national park) or cultural landscapes (nature park), as well as higher or lower restrictions imposed on outdoor recreation activities. For marketing purposes, it might therefore be better to highlight the nature experiences and related offers - which are requested by nearly all segments - than to rely only on the brand name of the protected area. Especially the categories of national park and biosphere reserve are perceived in an ambivalent way by several segments.

The significant and diverse supply of nature experience offers and related tourism products by PA, especially nature parks and national parks (Tab. 3), and their possible effect on tourism marketing related to PA, is currently underestimated and underused. Therefore, marketing based on nature experiences and education for sustainable development should receive greater consideration in destination planning and management in the future.

\section{Differences between the three categories of protected areas}

The presentation of the supply side highlights the significant differences in tourism related supply between the different categories of parks. National parks offer the strongest degree of protection, followed by biosphere reserves. Nature parks, in contrast, are more focused on outdoor recreation and landscape experience. Against this background, it was of great interest whether these differences are perceived by experienced and unexperienced alpine visitors.

The two most established PA categories, the national park and the nature park, are relevant for the destination choice of two segments with former alpine experience. The traditional tourist is significantly more interested in national parks than in other types of PA. National parks seem to guarantee the environmental conditions they expect, such as small villages, excellent hiking conditions and only traditional events. The more social and sport oriented visitors explicitly prefer nature parks, which support their preferences for events and a diverse cultural program, greater infrastructure and a much more sophisticated offer of sports - all of which is unlikely in 
a national park. The case of these two segments with former alpine experience seems to represent good product-market matching, as visitor preferences and the goals of the PA obviously coincide (Tab. 3). Thus, conflicts are less likely, and satisfaction with the chosen destination, as well as repeat visits, are likely to increase.

The tourist without former alpine experience, on the other hand, seems to have no clear understanding of the different types of PA. For this tourist group, two general outcomes can be described:

- For both the sport and action oriented tourist and the undemanding potential tourist, PA are an irrelevant attribute in the process of destination choice.

- For the nature-interested potential tourist it does not seem to be the specific type of protected area itself which is attractive, but the mere existence of a protected area of any type seems to provide a certain assurance of finding the preferred location - small and quiet, with traditional and unsophisticated offers. This may explain why this segment prefers any type of protected area without any specification.

For none of the three segments without former alpine experience, the type of protected area matters. The supply-side, determined by park management, and the specification and differences between the conservation categories are not relevant.

\section{Relevant other attributes for destination choice in the alpine area}

The main criteria when choosing an alpine destination, for those with former experience and for repeat visitors, are the preferred communities on the one hand and the preferred activities on the other. Somewhat surprisingly, marginal changes to the vacation price were less relevant. The protected area can be perceived as a part of the preferred location, ensuring, for example, peace and quiet and close contact to the environment in small villages.

For the unexperienced alpine tourist, it is the activities that constitute the main criteria for destination choice. The sport and action oriented clientele also tends to be price sensitive when choosing a destination. Overall, PA have very little influence. The tourists without alpine experience seek experiences, including nature experience, and a diverse program with local events addressed to the target group.

Both types of tourists, experienced and unexperienced, are mainly attracted by the unique experiences which can be expected when visiting the alpine area. Nature experiences, environmental education and of course the typical alpine activities (hiking, climbing etc.) should therefore be used as the key elements of any marketing strategy. The existence of protected areas, on the other hand, appears to be less relevant overall to the decision making process.

\section{Contribution to international studies on tourism and $P A$}

The discussion about the economic benefits accruing from PA is an ongoing one. Most studies focus on visitors within the boundaries of the park or the immediately surrounding communities (see literature review in Tab. 1). Almost by definition, responses to these studies will typically confirm a high level of satisfaction with destination choice and a positive attitude towards the park and the local landscape. Thus, a fundamental question in the research on the interactions between PA and tourism is whether this type of investigation should only focus on those visitors who actually know that they are in a park and likely have chosen this destination explicitly for that purpose (MAYER 2013; JOB et al. 2005, 2009), or if one should also include those guests (as suggested by ScHMITZ-VELTIN 2005) who share the same motives and interests, especially the enjoyment of attractive landscapes, but who are not interested in the brand and the predicated landscape.

Our findings show that a significant number of tourists, even first time visitors, have a fairly clear understanding of their expectations when sojourning in nature, but they are less concerned about the presence of PA or their specific classification status. It seems that the traditional protected area focused visitor research introduces a significant bias and ultimately underestimates the value of the protected area. Our results provide an idea of how significant this bias is for PA in the European Alps.

In his book about the economic benefit of the National Park Bayerischer Wald (Bavarian Forest), MAYER $(2013,482)$ discusses this issue of 
framing the relevant visitor population for this type of research (i.e. should a study focus on actual visitors only, or also include latent demand). In the end, Mayer defends the classical approach with the conservative argument that any other approach would contradict common knowledge and the international literature that so forcefully (and conveniently) highlights positive contributions of parks worldwide. Actually, he perceives this question as merely hypothetical and it is simply for that reason that no relevant research has been undertaken in this direction so far. Therefore, we consider our arguments presented here important, as they fill this research gap and hopefully contribute to this interesting discussion.

MAYER (2013, 482f.) introduces another methodological question to the discussion about the relevance of parks for destination choice, by asking respondents in the National Park Bayerischer Wald: "Would you have visited the park also without it being a national park?" This effort to learn more about the relevance of parks for destination choice was criticized by respondents as well as the media. We believe that this interesting research question could have been answered more adequately with multivariate methods. Our findings show that respondents are able to handle a large number of attributes adequately if the choice sets are designed in a relevant manner. The application of multivariate approaches to national park research, of which only a few exist (Tab. 1), would help to answer these and other demanding questions which might be useful for both tourism and park management.

\section{Conclusions}

The paper investigated the role that parks and PA might play in the process of destination choice in the European Alps. The arguments combined aspects of tourism supply and demand by 1) assessing the legislative and regulatory framework of PA in all seven alpine nations with regards to its support for tourism development, and 2) analysing the role PA play in influencing the demand for a destination.

Both these analyses provide rather unique perspectives on the relationship between one of the potentially major tourism resources and the demand. Although the legal background for PA in the alpine area is very diverse and scattered over 37 different legal documents, three main catego- ries of PA cover the vast majority of PA and can be used for comparative purposes across all alpine countries.

Very few studies on PA have been undertaken from a true tourism perspective. Instead, tourism related analysis of PA has mostly focused on their economic impact. Classical tourism research on destination demand is characterized by two deficiencies: 1) the role of natural resources is not investigated as thoroughly as aspects of the destination and tourism infrastructure, and 2) most demand analyses are based on samples of visitors, and thus carry an inherent bias, as only tourists who have already made a positive choice in favour of a given destination are part of the sample. Therefore we employed a demand study for generic alpine product features in one of the major areas of origin of alpine tourism, in Germany.

The analyses of the supply side, screening all legal documents against a set of eleven criteria, revealed a basic comparability of the instruments in principle, but also relevant differences with regards to tourism destination development. The survey-based analysis of the demand side aimed to reveal whether these differences are also relevant for the tourists themselves.

The results of the demand analysis show that the role of PA for destination marketing is not as relevant as reported by respective literature. Several reasons might lead to this discrepancy:

1) Most studies do not use multivariate approaches for determining the importance of destination attributes. When a specific destination feature is evaluated by respondents singly (e.g. in a Likert rating scale), it is likely to receive a positive value as no trade-off against alternatives is required.

2) A destination-based study only asks about the importance of a PA if there is a PA nearby. And the more prominent the PA features in the promotion of a destination, the less likely it is that respondents who are adverse to a PA will actually have chosen that destination. In contrast, a survey in the area of origin provides rather unique information.

3) In our study, one major reason for this discrepancy might be the fact that only alpine experienced visitors have a clear understanding of the implications of having a protected area adjacent to a holiday destination. The 
unexperienced alpine visitor is not able to value this aspect in his or her decision making process. The alpine experienced tourist is also more likely to distinguish between the various types of PA such as national park and nature park. In addition, the respective segments prefer those types of protected area which are more likely to meet their main interests. The sport and social-oriented segment focuses more on the nature park while the elderly traditional alpine tourist is more attracted by the national park. Supply and demand match here quite well.

The importance of PA, when compared to all other attributes, is rather low. Especially for the unexperienced alpine tourist, the marketing effect of PA is limited by the fact that only one segment expects somewhat unspoiled nature, quietness and smaller settlements. Therefore, only the nature interested potential tourist is likely to take PA into account in his or her destination choice. For the other segments, the set of possible activities is much more relevant. There is one exception: nature experience offers are attractive for nearly all tourists, experienced and unexperienced, and across all segments. Nature experience offers, one important supply by all types of $\mathrm{PA}$, are of high relevance within the destination choice. This aspect should be used and communicated in destination marketing based on PA.

\section{References}

Adamowicz, W. / Swait, J. / Boxall, P.C. / Louviere, J. / Williams, M. (1997): Perceptions versus objective measures of environmental quality in combined revealed and stated preference models of environmental valuation. In: Journal of Environmental Economics and Management, (32) $1,65-84$.

AJZEN, I. (1985): From intentions to actions. A theory of planned behavior. In: Kuhl, J. / Beckmann, J. (Eds.): Action control. From cognition to behavior. Berlin/Heidelberg, $11-39$.

AJZEN, I. (1991): The theory of planned behavior. In: Organizational Behavior and Human Decision Processes, (50)2, 179-211.

Ammer, U. / PröBstl, U. (1991): Freizeit und Natur. Hamburg.

Backhaus, N. / Buser, C. / Butticaz, M. / Jorio, D. / Speich, M. (2013): Wirtschaftliche Auswirkungen des Sommertourismus im UNESCO Biosphärenreservat Val Müstair Parc Naziunal. Zürich. (Human Geography Series / Schriftenreihe Humangeographie, Band 27).

BAgOzZi, R. P. / NATARAAJAN, R. (2000): The year 2000: Looking forward. In: Psychology \& Marketing, (17)1, 1-11.
BÄtZiNG, W. (2002): Der Stellenwert des Tourismus in den Alpen und seine Bedeutung für eine nachhaltige Entwicklung des Alpenraums. In: Luger, K. / Rest, F. (Hrsg.): Der Alpentourismus. Entwicklungspotenziale im Spannungsfeld von Kultur, Ökonomie und Ökologie. Innsbruck, 175196. (Tourismus: transkulturell \& transdisziplinär, Bd. 5).

Bell, S. / Simpson, M. / Tyrväinen, L. / Sievänen, T. / PRÖBSTL, U. (2009): European forest recreation and tourism. A Handbook. London.

Boxall, P.C. / Adamowicz, W. / Swait, J. / Williams, M. / LOUVIERE, J. (1996): A comparison of stated preference methods for environmental valuation. In: Ecological Economics, (18)3, 243-253.

BOXALl, P. / ADAMOWICZ, W. (2002): Understanding heterogeneous preferences in random utility models. A latent class approach. In: Environmental and Resource Economics, 23, 421-446.

BRAU, R./ CAO, D. (2005): Uncovering the macrostructure of tourists' preferences. A choice experiment analysis of tourism demand to Sardinia. Cagliari. (University of Cagliari, Centre for North South Economic Research, Working Papers 2005/14; Internet: www.crenos.it, 1.9.2013).

BuCKLEY, R. (2004): The effects of world heritage listing on tourism to Australian national parks. In: Journal of Sustainable Tourism, (12)1, 70-84.

Campbell, D. / Hutchison, W. G. / Scarpa，R. (2006): Quantifying the landscape benefits arising from the Rural Environment Protection Scheme: results from a public survey. In: Tearmann - Irish Journal of Agri-Environmental Research, 5, 1-12.

Cooper, C. / Fletcher, J. / Fyall, A. / Gilbert, D. / WANHILL, S. (2005): Tourism. Principles and practice. FT Prentice Hall, Edinburgh.

DiXON, J.A. / SHERMAN, P. B. (1991): Economics of protected areas. In: Ambio, (20)2, 68-74.

EAGLES, P. (2001): International trends in park tourism. EUROPARC 2001 Conference, Matrei, Austria. (Paper for the Federation of Nature and National Parks in Europe).

ENGLUND, K. B. (2005): Integrating GIS into choice experiments. An evaluation of land use scenarios in Whistler, BC. Burnaby, BC. (Simon Fraser University, Master Thesis).

FleischHacker, V./ PAuer, P. (2001): Nationalparks und Tourismus in Österreich. Tulln. (Institut für Touristische Raumplanung - ITR).

Forster, S. / SiEgrist, D. (2009): Erfolgsfaktoren für den Tourismus in Pärken und UNESCO-Gebieten. In: Siegrist, D. / Stremlow, M. (Hrsg.): Landschaft, Erlebnis, Reisen. Zürich, 107-119.

Franch, M. / Martini, U. / Buffa, F. / PARISI, G. (2008): 4L tourism (landscape, leisure, learning and limit). Responding to new motivations and expectations of tourists to improve the competitiveness of Alpine destinations in a sustainable way. In: Tourism Review, (63)1, 4-14.

George, E. W. / Mair, H. / Reid, D. G. (2009): Rural tourism development. Localism and cultural change. Bristol.

Getzner, M. / Jungmeier, M. (2002): Conservation policy and the regional economy. The regional economic impact of Natura 2000 conservation sites in Austria. In: Journal of Nature Conservation, 10, 25-34. 
G. I. S. Alparc (2013): Zahlen der alpinen Schutzgebiete. Internet: http://www.alparc.org/de/die-schutzgebiete/zahlender-asg, 28.6.2014.

GMWC (1995) cited after WIRTH, V. (2010).

Gurung, D. B. / SEeland, K. (2008): Ecotourism in Bhutan. Extending its benefits to rural communities. In: Annals of Tourism Research, (35)2, 489-508.

HAIDER, W. / EwING, G. O. (1990): A model of tourist choices of hypothetical caribbean destinations. In: Leisure Sciences, (12)1, 33-47.

HAIDER, W. / Hunt, L. (2002): Aesthetic quality of northern Ontario's forested shorelines. In: Environmental Management, (29)3, 324-334.

Hall, C.M. / Piggin, R. (2002): Tourism business knowledge of World Heritage sites: a New Zealand case study. In: The International Journal of Tourism Research, 4, 401-411.

Hammer, T./Siegrist, D. (2008): Protected areas in the Alps. The success factors of nature-based tourism and the challenge for regional policy. In: Gaia, (17)1, 152-160.

Heintel, M. / Weixlbaumer, N. (2009): Die regionalökonomische Bedeutung des österreichischen Naturparktourismus. Das Beispiel Burgenland. In: Natur und Landschaft, (84)7, 315-321.

Hensher, D.A./Rose, J.M./ Greene, W.H. (2005): Applied choice analysis. A primer. Cambridge.

Higgins-Desbiolles, F. (2011). Development on Kangaroo Island. The controversy over Southern Ocean Lodge. In: Dredge, D. / Jenkins, J. (Eds.): Stories of practice. Tourism policy and planning. Farnham, UK, 105-131.

HunZiker, M. / Felber, P. / Gehring, K. / Buchecker, M. / Bauer, N. / Kienast, F. (2008): How do different societal groups evaluate PA and future landscape changes? Results of two empirical studies in Switzerland. In: Mountain Research and Development, (28)2, 140-147.

HUyBers, T. (2004): Destination choice modelling - To label or not to label? Tourism modelling and competitiveness. Implications for policy and strategic planning, October/November 2003. Internet: http://citeseerx.ist.psu.edu/viewdoc/ download?doi=10.1.1.197.267\&rep=rep1\&type=pdf, 1.9 . 2013.

IUCN (International Union for Conservation of Nature and Natural Resources) (1994): Richtlinien für ManagementKategorien von Schutzgebieten. Gland.

Job, H. / Harrer, B. / Metzler, D. / Hajizadeh-Alamdary, D. (2005): Ökonomische Effekte von Großschutzgebieten. Untersuchung der Bedeutung von Großschutzgebieten für den Tourismus und die wirtschaftliche Entwicklung der Region. Bonn-Bad Godesberg. (BfN-Skripten 135, Internet: http://www.bfn.de/fileadmin/MDB/documents/skript135. pdf).

Job, H. / Metzler, D. / Vogt, L. (2003): Inwertsetzung alpiner Nationalparks. Eine regionalwirtschaftliche Analyse des Tourismus im Alpenpark Berchtesgaden. (Münchner Studien zur Sozial- und Wirtschaftsgeographie, 43).

Job, H. / Kraus, F. / Merlin, C. / Woltering, M. (2013): Wirtschaftliche Effekte des Tourismus in Biosphärenreservaten Deutschlands. Bonn-Bad Godesberg. (Naturschutz und Biologische Vielfalt, Heft 134).
JoB, H. / PAESLER, F. (2013): Links between nature-based tourism, protected areas, poverty alleviation and crises. The example of Wasini Island (Kenya). In: Journal of Outdoor Recreation and Tourism, 1-2, 18-28.

KAMmer, M. (2005): Schutzgebiete und deren Funktion für die Regionalentwicklung. Ein Vergleich zwischen Neuseeland und Österreich. Wien. (Dipl.-Arbeit Universität für Bodenkultur)

Kelly, J. / Haider, W. / Williams, P. W. / Englund, K. (2007): Stated preferences of tourists for eco-efficient destination planning options. In: Tourism Management, (28)2, 377-390.

KIRIG, A. / ScHICK, I. (2008): Neo-Nature. Der große Sehnsuchtsmarkt Natur. Wien. (Zukunftsinstitut GmbH).

KLEINHENZ, G.(1982): Fremdenverkehr und Nationalpark. Grafenau.

KoHLER, Y. (2013): Die Rolle der Schutzgebiete in der Regionalentwicklung. Eine Reise durch die Alpen. In: Verband der Naturparke Österreichs (Hrsg.): Naturparke und nachhaltige Regionalentwicklung. Graz, 14-23.

KoRnMÜLler, S. (2008): Das Online-Panel als Instrument der Primärforschung. Möglichkeiten und Grenzen in der Online-Primärforschung. Saarbrücken.

KÜPFER, I. (2000): Die regionalwirtschaftliche Bedeutung des Nationalparktourismus untersucht am Beispiel des Schweizerischen Nationalparks. Zürich. (Nationalparkforschung in der Schweiz Nr. 90).

LANDAuer, M. / Haider, W. / PröBstl-Haider, U. (2014): The Influence of culture on climate change adaptation strategies. Preferences of cross-country skiers in Austria and Finland. In: Journal of Travel Research, 59, 95-109.

Lehar, G. / HAusberger, K. / Fuchs, L. (2004): Besucherzählung, Motiv- und Wertschöpfungserhebung im Nationalpark Hohe Tauern und im Naturpark Riesenferner-Ahrn. Innsbruck

LEIBENATH, M. / BADURA, M. (2005): Manual for the evaluation of Natura 2000 sites in economic terms. Dresden. (Baltic Environmental Forum).

LIPING, C.A. (2002): Cooperative branding for rural destinations. In: Annals of Tourism Research, (29)3, 720-742.

Louviere, J./ Timmermans, H. (1990): Stated preference and choice model applied to recreation research. A review. In: Leisure Sciences, 12, 9-32.

Louviere, J. / Hensher, D.A. / Swait, J.(2000): Stated choice methods. Cambridge, UK.

March, R. / Woodside, A.G. (2005): Tourism behavior. Travellers' decisions and actions. Oxon.

Mathieson, A. / Wall, G. (1982): Tourism: Economic, physical and social impacts. London.

Mayer, M. (2013): Kosten und Nutzen des Nationalparks Bayerischer Wald. Eine ökonomische Bewertung unter Berücksichtigung von Tourismus und Forstwirtschaft. München.

MAYER, M./JoB, H. (2014): The economics of protected areas - a European perspective. In: Zeitschrift für Wirtschaftsgeographie, (58)1, 73-97.

Messerli, P. (1989): Mensch und Natur im alpinen Lebensraum. Risiken. Bern. 
MontGOMERY, D. C. (2001): Design and analysis of experiments. New York.

Morley, C. (1994): Experimental destination choice analysis. In: Annals of Tourism Research, (21)4, 780-791.

Mose, I. / Weixlbaumer, N. (2003): Großschutzgebiete als Motoren einer nachhaltigen Regionalentwicklung? In: Verband der Naturparke Österreichs (Hrsg.): Wer macht's, wer zahlt's, was bringt's? Naturparke und Regionalentwicklung. Graz, o. S.

DEL Negro, M. (2009): Schutzgebiete in Slowenien mit besonderer Berücksichtigung des Alpenraums. Wien.

Netzwerk alpiner Schutzgebiete (2002): Typologie der alpinen Schutzgebiete. Gesetzliche Grundlagen und Schutzformen. Gap. (Dossier des Alpinen Netzwerks Nr. 8).

OBUA, J./HARDING, D.M. (1996): Visitor characteristics and attitudes towards Kibale National Park, Uganda. In: Tourism Management, (17)7, 495-505.

Olschowy, G. (1978): Natur und Umweltschutz in der Bundesrepublik Deutschland. Oxon.

Österreich Werbung (2012): T-MONA Urlauberbefragung. Internet: http://www.austriatourism.com/wp-content/ uploads/2012/07/2013i_b2b-info-t-mona.pdf, 1.9.2013.

Perlik, M. (2006): The specifics of amenity migration in the European Alps. In: Moss, L.A.G. (Ed.): The amenity migrants. Seeking and sustaining mountains and their cultures. Wallingford, UK/Cambridge, MA.

Pine, B. J. / GilmoRe, J. H. (1999): The experience economy. Work is theatre \& every business a stage. Boston.

PRÖBSTL, U. (2004): Nature parks as an instrument to protect mountainous regions. A comparison in Central Europe. In: Ito, T. / Tanaka, N. (Eds.): Social roles of forests for urban population. Forest recreation, landscape, nature conservation, economic evaluation and urban forestry. Tsukuba, $156-169$.

PRÖBSTL, U. (2006): Tourism marketing for protected areas under the constraints of nature conservation. In: Job, H. / Li, J. (Eds.): Natural heritage, ecotourism and sustainable development. Potentials and pitfalls for China. Regensburg, 87-94. (Münchner Studien zur Sozial- und Wirtschaftsgeographie, 45).

PRÖBSTL, U. (2010): Strategies for tourism development in peripheral areas in the alpine area. In: Brebbia, C.A./Pineda, F.D. (Eds.): Sustainable tourism IV. Southampton/ Boston, 3-11.

PRÖBSTL-HAIDER, U. (2013): Regionalwirtschaftliche Effekte in Naturparken. In: Verband der Naturparke Österreichs (Hrsg.): Naturparke und nachhaltige Regionalentwicklung. Graz, 24-38.

PRÖBSTL, U./WIRTH, V. (2011): Nachhaltige Waldbewirtschaftung im Naturpark Mürzer Oberland. Endbericht im Projekt „Modellregion für nachhaltige Waldwirtschaft im Naturpark Mürzer Oberland“. Wien. (Universität für Bodenkultur Wien).

Pröbstl, U. / Wirth, V. / Elands, B. / Bell, S. (Eds.) (2010): Management of recreation and nature based tourism in $\mathrm{Eu}-$ ropean forests. Heidelberg.

PrÖBStl-Haider, U. / HAider, W. (2013): Tools for measuring the intention for adapting to climate change by winter tourists: some thoughts on consumer behavior research and an empirical example. In: Tourism Review, (68)2, 44-55. PröBstl-Haider, U./ Wirth, V. / Haider, W. (2014): Wie viel „Natur“ suchen deutsche Urlauberinnen und Urlauber in den Alpen? Eine Quellgebietsstudie bezogen auf den Sommertourismus. In: Natur und Landschaft, (89)1, 26-32. Reinius, S. W. / Fredman, P. (2007): Protected areas as attractions. In: Annals of Tourism Research, (34)4, 839-854.

SAAyman, M./SAAYMAn, A. (2006): Estimating the economic contribution of visitor spending in the Kruger National Park to the regional economy. In: Journal of Sustainable Tourism, (14)1, 67-81.

SCARPA, R. / ThIEME, M. (2005): Destination choice models for rock climbing in the Northeastern Alps. A latent-class approach based on intensity of preferences. In: Land Economics, (81)3, 426-444.

SCHEURER, T. / KÜPFER, I. (1997): Was können Schutzgebiete im Alpenraum zur regionalwirtschaftlichen Entwicklung beitragen? In: Revue de Géographie Alpine, 2, 113-130.

Schlich, R. / Simma, A. / Axhausen, K. W. (2002): Zielwahl im Freizeitverkehr. Zürich. (Arbeitsbericht Verkehrsund Raumplanung Eidgenössische TH Zürich, Institut für Verkehrsplanung und Transportsystem).

Schmitz-Veltin, A. (2005): Der Wirtschaftsfaktor Tourismus in Nationalparken und Biosphärenreservaten als Beitrag zur nachhaltigen Regionalentwicklung. Wechselspiel zum Naturschutz am Beispiel von Berchtesgaden und Rhön. In: Naturschutz und Landschaftsplanung, (37)4, 115-121.

SCHwEIGGL, M. (1993): Naturparke in Südtirol. Bozen.

Siegrist, D. / Aufdereggen, M. / LintZMeyer, F. / Spiess, H. (2007): Ökonomische Analyse von Regionalen Naturpark-Projekten im Kanton Bern. Rapperswil/Winterthur. (FTL-HSR/INE-ZHW).

Siegrist, D. / Stremlow, M. (Hrsg.) (2009): Eine neue Qualität für Tourismus, Natur und Landschaft. In: Siegrist, D. / Stremlow, M. (Hrsg.): Landschaft - Erlebnis - Reisen. Naturnaher Tourismus in Pärken und UNESCO-Gebieten. Zürich, 239-247.

Siegrist, D. / WASEM, K. (2009): Was bedeutet Erlebnisqualität im naturnahen Tourismus? In: Siegrist, D. / Stremlow, M. (Hrsg.): Landschaft - Erlebnis - Reisen. Naturnaher Tourismus in Pärken und UNESCO-Gebieten. Zürich, 157169.

SPÖ-Klubenquete (2012): Tourismus im ländlichen Raum. Internet: http://www.ots.at/presseaussendung/OTS_2012 1123_OTS0131/dienstag-27-november-spoe-klub-enquetetourismus-im-laendlichen-raum, 1.9.2013.

Statistik Austria (2012): Bevölkerungsstand. Wien.

StMWIVT (Bayerisches Staatministerium für Wirtschaft, Infrastruktur, Verkehr und Technologie) (2013): Gesamtfortschreibung des Landesentwicklungsprogramms Bayern (LEP) - Entwurf des Landesentwicklungsprogramms (LEP-E) (20.6.2013). Internet: http://www.stmwi.bayern. de/landesentwicklung/instrumente/landesentwicklungsprogramm/landesentwicklungsprogramm-bayern-lep/, 3.7.2014.

Studienkreis für Tourismus und Entwicklung (2005): Urlaubsreisen und Umwelt. Eine Untersuchung über die Ansprechbarkeit der Bundesbürger auf Natur- und Umwelt- 
aspekte in Zusammenhang mit Urlaubsreisen. Starnberg. (Schriftenreihe für Tourismus und Entwicklung).

Tempesta, T./Thiene, M. (2000): Benefits and costs of tourism and outdoor recreation in the Natural Park of the Ampezzo Dolomites (Veneto, Italy). In: Proceedings of the Conference "Agritourism and Rural Tourism. A key option for the Rural Integrated and Sustainable Development Strategy", Perugia, 21-22 September. Internet: http://intra.tesaf. unipd.it/people/tempesta/Articoli\%20per\%20sito\%20TT/ Benefit $\% 20$ and $\% 20$ cost $\% 20$ Cortina.pdf, 27.4.2014.

Thompson, I.B. (2008): Sustainable rural development in the context of a high mountain national park. The Parc Nacional de la Vanoise, France. In: Scottish Geographical Journal, (115)4, 297-318.

TraIN, K. (2003): Discrete choice methods with simulation. Cambridge, UK.

Verband der Deutschen Naturparke (VDN) (2010): Qualitätsoffensive Naturparke. Bonn.

WeILER, S. / SEIDL, A. (2004): What's in a name? Extracting econometric drivers to assess the impact of national park designation. In: Journal of Regional Science, (44)2, 245-262.

WeiXlbaumer, N. (2009): Schutzgebietslandschaften als Möglichkeitsräume für einen naturnahen Tourismus. In: Siegrist, D. / Stremlow, M. (Hrsg.): Landschaft - Erlebnis - Reisen. Naturnaher Tourismus in Pärken und UNESCOGebieten. Zürich, 191-203.

Weixlbaumer, N./ Gamper, C./ Gruber, K. (2007): NABU. Naturparke Burgenland. Bedeutung der Naturparke Burgenlands für den Tourismus und die wirtschaftliche Entwicklung der Region. Wien. (Institut für Geographie und Regionalforschung der Universität Wien, Projektendbericht).

WirTH, V. (2010): Entwicklungsperspektiven für den Alpentourismus unter Berücksichtigung von Klimawandel und geschützter Landschaft: Modellierung von Destinationsentscheidungen. Wien. (Diss. Institut für Landschaftsentwicklung, Erholungs- und Naturschutzplanung - ILEN, Universität für Bodenkultur Wien).

Wirth, V. / PrÖBSTL, U. (2007): The Tourists' view on protected areas. Symposium „Management of Tourism in Protected Areas", 26.-28.9.2007, Otepää.

Woodside, A. G. / King, R. (2001): Tourism consumption systems. Theory and empirical research. In: Journal of Travel and Tourism Research, (10)1, 3-27.

Woodside, A. G. / Lysonski, S. (1989): A general model of traveler destination choice. Journal of Travel Research, (27)1, 8-14.

WWF Deutschland (1999): Nationalparke. Bundesweite EMNID-Umfrage Mai 1998. In: Liebmann, F./Rösner, H.-U. (Hrsg.): Die Bedeutung von Nationalparken für den Tourismus. Band 7. Frankfurt am Main, 33-44.

ZANON, B. / GENELETTI, D. (2011): Integrating ecological, scenic and local identity values in the management plan of an Alpine Natural Park. In: Journal of Environmental Planning and Management, (54)6, 833-850.

ZuRC, J. (2008): Opportunities for tourism in and around protected areas in Slovenia. In: Participating in nature. Communities and protected areas in Central and Eastern Europe. Internet: http://www.eci.ox.ac.uk/research/humaneco/romania-conference08.php, 27.4.2014. 


\section{Annex}

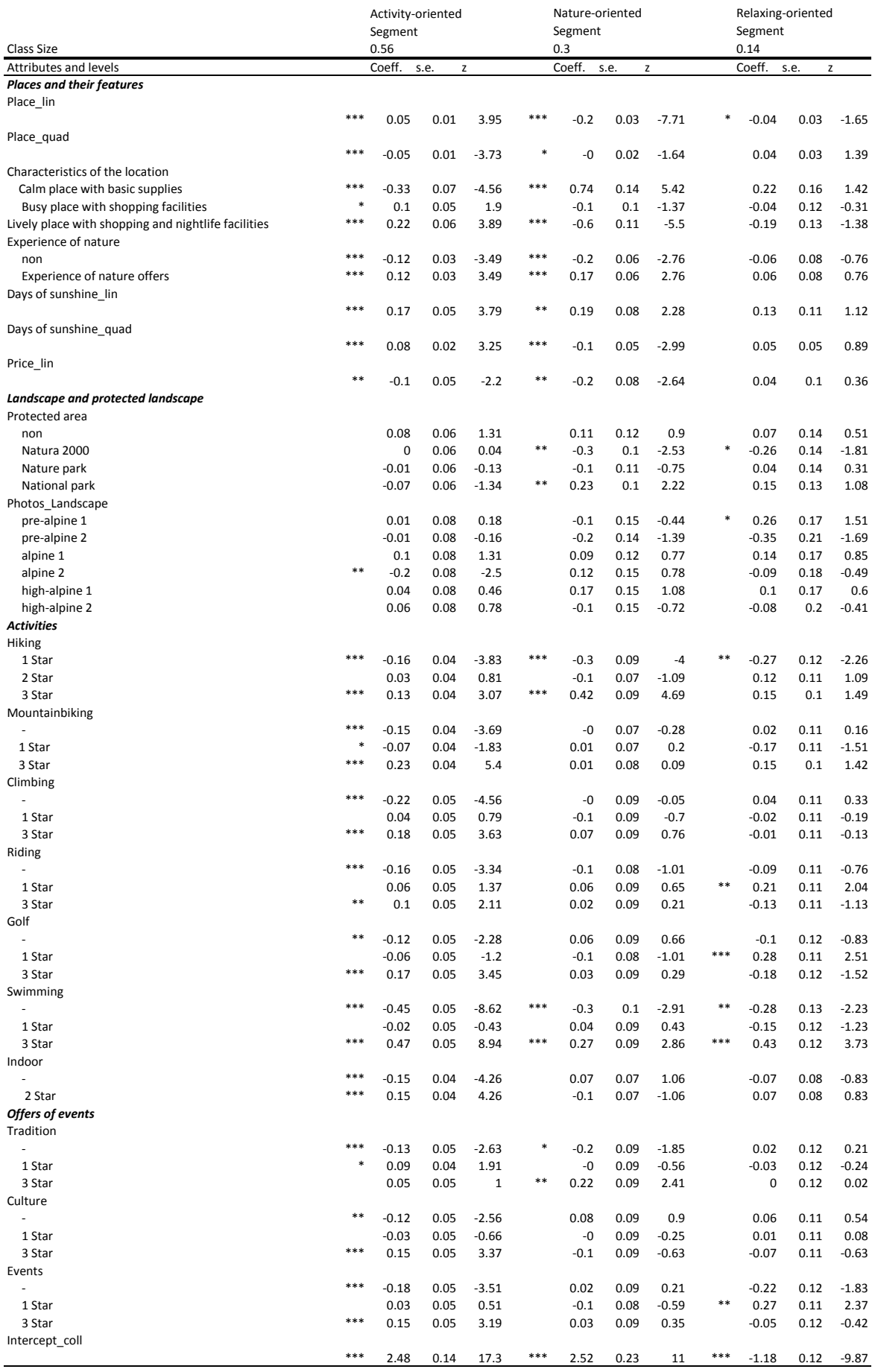

